\title{
Degradation of Trichloroethylene in Groundwater Using Iron Catalyzed Calcium Peroxide Systems
}

\author{
Kegang Zhang ${ }^{1}$, Xiaodong Wang ${ }^{1, *}$, Xiaohui Zhang ${ }^{1}$, and Shengjie Peng ${ }^{1}$ \\ ${ }^{1}$ School of Civil Engineering and Architecture, University of Jinan, Jinan 250022, China
}

\begin{abstract}
The application of calcium peroxide $\left(\mathrm{CaO}_{2}\right)$ activated with ferrous ion chelate sodium citrate (TCD) to stimulate the degradation of trichloroethylene (TCE) was investigated. The experimental results show that the removal efficiency of TCE increases first and then decreases with the increase of $\mathrm{CaO}_{2}$ and $\mathrm{Na}_{2} \mathrm{~S}_{2} \mathrm{O}_{8}$ dosage; the chelation ratio of $\mathrm{Fe}(\mathrm{II}) / \mathrm{TCD}$, too much or too little, will affect the removal efficiency of TCE; when the molar ratio of $\mathrm{CaO}_{2} / \mathrm{Fe}(\mathrm{II}) / \mathrm{TCD} / \mathrm{TCE}$ is $18 / 6 / 6 / 1$, the removal efficiency of TCE is the highest, reaching $97.99 \%$ within $200 \mathrm{Min}$. The results demonstrated that the technique of $\mathrm{CaO}_{2}$ activated with ferrous ion is a highly promising technique in in situ chemical oxidation (ISCO) remediation in TCE contaminated sites.
\end{abstract}

\section{Introduction}

Since the second half of the 20th century, TCE has been widely used as industrial solvent, household cleaner and metal degreaser ${ }^{[1]}$.However, due to improper disposal during production and use, as well as leakage from underground storage tanks ${ }^{[2]}$, TCE has become one of the most common pollutants in soil and groundwater ${ }^{[3]}$.

TCE as a human carcinogen and priority control pollutants persist in the environment (TCE, low viscosity, migration ability strong, can not only exists in the soil in the form of drops ${ }^{[4]}$, also can through the gap to deeper soil aquifer ${ }^{[5]}$ (Figure 1), such as in the soil half-life of about 0.5-1.5 years, in the groundwater can reach 4.5 years $\left.{ }^{[6]}\right)$ Poses a serious threat to human health .There is evidence that long-term exposure to TCE may damage the human central nervous system, with major symptoms including nausea, facial numbness, dyskinesia and even death ${ }^{[7]}$. Therefore, in order to maintain the drinking safety of groundwater, it is necessary to study effective removal methods.

In recent years, more and more studies have been conducted on the oxidation of organic pollutants by $\mathrm{CaO}_{2}$. Studies have shown that $\mathrm{CaO}_{2}$ can slowly release $\mathrm{H}_{2} \mathrm{O}_{2} \quad\left(0.47 \mathrm{gH}_{2} \mathrm{O}_{2} / \mathrm{gCaO}_{2}\right)$, and the release rate is controllable, and the repair effect is more significant than that of $\mathrm{H}_{2} \mathrm{O}_{2}{ }^{[8-9]}$, which has become an effective substitute for liquid $\mathrm{H}_{2} \mathrm{O}_{2}$. The equation of $\mathrm{CaO}_{2}$ and water is as follows ${ }^{[10]}$ :

$$
\begin{aligned}
& \mathrm{CaO}_{2}+\mathrm{H}_{2} \mathrm{O} \rightarrow 1 / 2 \mathrm{O}_{2} \uparrow+\mathrm{Ca}(\mathrm{OH})_{2} \downarrow \\
& \mathrm{CaO}_{2}+2 \mathrm{H}_{2} \mathrm{O} \rightarrow \mathrm{H}_{2} \mathrm{O}_{2}+\mathrm{Ca}(\mathrm{OH})_{2} \downarrow
\end{aligned}
$$

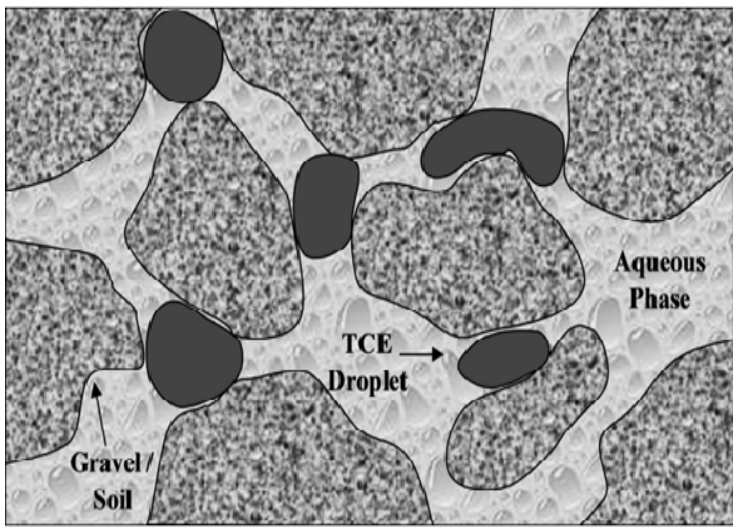

Fig.1. Distribution of DNAPL in the aquifer.

\section{Experimental Part}

\subsection{Experimental reagents and instruments}

\subsubsection{Experimental reagents}

The TCE and $\mathrm{Na}_{2} \mathrm{~S}_{2} \mathrm{O}_{8}$ used in this experiment were all produced by Tianjin Da Mao chemical reagent factory, $\mathrm{CaO}_{2}$, trisodium citrate (TCD, China national pharmaceutical group), $\mathrm{FeSO}_{4} \cdot 7 \mathrm{H}_{2} \mathrm{O}$, isopropanol, methanol, sodium chloride and anhydrous sodium sulfate (Tianjin Beilian Fine Chemical Co., Ltd).

\subsubsection{Experimental instruments}

\footnotetext{
* Corresponding author: 13853189137@,163.com (X. Wang)
} 
Adjustable thermostatic shaker (ZWY-240), electronic analytical balance (BSA2201), pH meter (FE20,), Gas chromatograph (7890B).

\subsection{Experimental methods}

All experiments in this part were static batch experiments, which were conducted in a $250 \mathrm{ml}$ headspace culture bottle and placed in a constant temperature culture shock box. A certain amount of samples was taken at a preset time point and the reaction was quickly stopped with methanol, Isopropanol and Trichloromethane ${ }^{[6]}$, and the content of TCE in the solution was determined .The experimental conditions were as follows: $\mathrm{pH}=7$, the temperature was $25^{\circ} \mathrm{C}$, the initial concentration of TCE was $21 \mathrm{mg} / \mathrm{L}(0.16 \mathrm{mmol} / \mathrm{L})$, and the rotating speed of the constant temperature culture shock box was $165 \mathrm{r} / \mathrm{min}$.

\section{Results and discussion}

\subsection{Effect of $\mathrm{CaO}_{2}$ dosage on TCE removal rate}

As can be seen from Figure 2, when the concentration of TCD-Fe ${ }^{2+}$ is fixed and the dosage of $\mathrm{CaO}_{2}$ is changed, the degradation effect of TCE is different. When the dosage of $\mathrm{CaO}_{2}$ increased from $0.96 \mathrm{mmol} / \mathrm{L}$ (the ratio of $\mathrm{CaO}_{2}$ to TCE was $6 / 1$ ) to $3.84 \mathrm{mmol} / \mathrm{L}$ (the ratio of $\mathrm{CaO}_{2}$ to TCE was 24/1), the removal rate of TCE continued to increase, and the removal rate of TCE increased from $59.9 \%$ to $99.4 \%$ in the reaction time of $200 \mathrm{~min}$. The main reason are that when $\mathrm{CaO}_{2}$ meets water, it can produce $\mathrm{H}_{2} \mathrm{O}_{2}$, which is catalyzed by $\mathrm{Fe}^{2+}$ to produce $\mathrm{HO} \cdot$ to degrade TCE. Studies have shown that the generation of $\mathrm{H}_{2} \mathrm{O}_{2}$ by $\mathrm{CaO}_{2}$ conforms to the zero-order reaction kinetic model, and the amount of $\mathrm{CaO}_{2}$ has no effect on release rate constant of $\mathrm{H}_{2} \mathrm{O}_{2}$, which should be paid attention to in engineering practice.

When the dosage of $\mathrm{CaO}_{2}$ continued to increase to $4.8 \mathrm{mmol} / \mathrm{L}$ (the ratio of $\mathrm{CaO}_{2}$ to TCE was 30/1), the removal rate did not increase but slowed down, and the final removal rate within $180 \mathrm{~min}$ was $97.0 \%$. The reason may be that excessive $\mathrm{H}_{2} \mathrm{O}_{2}$ reacts with $\mathrm{OH} \cdot$ produced by a large amount of $\mathrm{CaO}_{2}$ (formula 3 and formula 4), which reduces the content of $\mathrm{OH} \cdot$ and thus reduces the removal rates ${ }^{[7]}$.

$$
\begin{gathered}
\mathrm{OH} \cdot+\mathrm{H}_{2} \mathrm{O}_{2} \rightarrow \mathrm{H}_{2} \mathrm{O}+\mathrm{HO}_{2} \\
\mathrm{OH} \cdot+\mathrm{OH} \cdot \rightarrow \mathrm{H}_{2} \mathrm{O}_{2}
\end{gathered}
$$

When the dosage of $\mathrm{CaO}_{2}$ increased from $2.88 \mathrm{mmol} / \mathrm{L}$ to $3.84 \mathrm{mmol} / \mathrm{L}$, the degradation effect of TCE did not increase significantly. For the sake of engineering economy, the dosage of $\mathrm{CaO}_{2}$ in subsequent experiments was $2.88 \mathrm{mmol} / \mathrm{L}$.

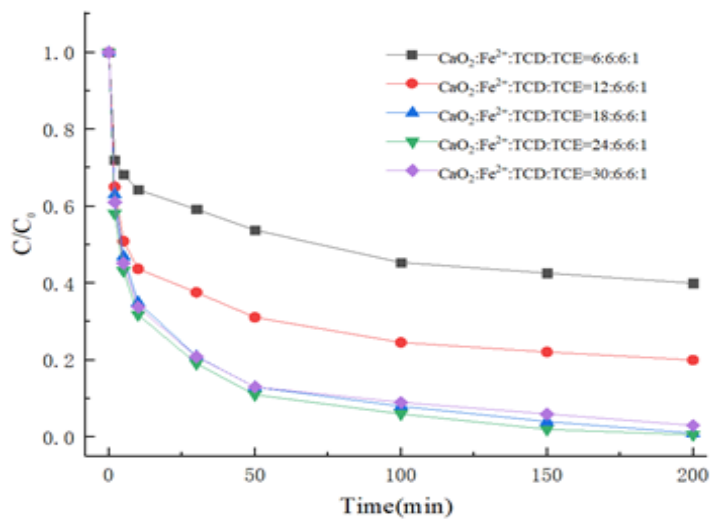

Fig.2. Effect of $\mathrm{CaO}_{2}$ dosage on TCE removal rate （[TCE $]_{0}=0.16 \mathrm{mmol} / \mathrm{L},\left[\mathrm{TCD}-\mathrm{Fe}^{2+}\right]_{0}=0.96 \mathrm{mmol} / \mathrm{L}, \mathrm{pH}=7$ )

\subsection{Study on the degradation effect of TCE based on $\mathrm{CaO}_{2}$ Fenton system}

As can be seen from Figure 3, TCE was not effectively degraded when $\mathrm{CaO}_{2}$ was added alone, and the removal rate was less than $6 \%$. This indicates that although $\mathrm{CaO}_{2}$ in water can slowly produce $\mathrm{H}_{2} \mathrm{O}_{2}$, the removal effect of $\mathrm{H}_{2} \mathrm{O}_{2}$ alone is not outstanding, indicating that the generation of its free radicals needs to be activated.This is consistent with the conclusion that $\mathrm{H}_{2} \mathrm{O}_{2}$ cannot remove refractory pollutants alone ${ }^{[8]}$.

In the $\mathrm{H}_{2} \mathrm{O}_{2} / \mathrm{TCD}-\mathrm{Fe}^{2+} / \mathrm{TCE}$ system, the degradation efficiency of TCE reached $99 \%$ after $10 \mathrm{~min}$. However, a large number of micro-bubbles were produced in the reaction process of this system, and the main reason may be that $\mathrm{H}_{2} \mathrm{O}_{2}$ dissolves to form $\mathrm{O}_{2}$ under neutral conditions .In the actual in-situ remediation of soil and groundwater, the half-life of liquid $\mathrm{H}_{2} \mathrm{O}_{2}$ is usually only a few minutes to a few hours [9], which makes the instability of $\mathrm{H}_{2} \mathrm{O}_{2}$ in the underground environment the maximum limit in the application of ISCO. Under the condition of neutral $\mathrm{pH}$ value ${ }^{[10,11]}$, disproportionation is the main loss form of $\mathrm{H}_{2} \mathrm{O}_{2}$. It consumes $\mathrm{H}_{2} \mathrm{O}_{2}$ without producing $\mathrm{OH} \cdot$, and the released $\mathrm{O}_{2}$ gas will block the pores around the injection well, promoting the volatilization of pollutants ${ }^{[12,13]}$, resulting in secondary pollution.

In the $\mathrm{CaO}_{2} / \mathrm{Fe}^{2+} / \mathrm{TCE}$ system, the degradation efficiency of TCE reached $42.9 \%$ after 2 min of reaction, but the subsequent reaction was extremely slow, and the removal rate of TCE was $50.8 \%$ at $200 \mathrm{~min}$. The main reason for this phenomenon were the precipitation deactivation of $\mathrm{Fe}^{3+}$ under neutral conditions, which also limited the application of Fenton reagent under neutral conditions .In the $\mathrm{CaO}_{2} / \mathrm{TCD} / \mathrm{Fe}^{2+} / \mathrm{TCE}$ reaction system, the removal rate in the first 2 minutes was only $36.9 \%$, but with the passage of reaction time, the reaction continued, and the final removal rate reached $97.99 \%$ within 200min.As can be seen from figure 3, the degradation trend of the above two reaction systems is significantly different, which may be caused by the addition of TCD to $\mathrm{Fe}^{2+}$ chelation in the system . On the one hand, TCD chelates $\mathrm{Fe}^{2+}$ to form relatively stable complexes. Although these complexes can catalyze Fenton-like reactions ${ }^{[14]}$, their activity is weaker than 
that of free state $\mathrm{Fe}^{2+[15]}$. On the other hand, TCD chelating $\mathrm{Fe}^{2+}$ can prevent iron ion precipitation and maintain the active state of iron ion under neutral conditions. Meanwhile, the presence of chelating agent can make the reaction from $\mathrm{Fe}^{3+}$ to $\mathrm{Fe}^{2+}$ more likely to occur. Rastogi A et al. showed that until the end of the reaction, there was no iron precipitation in the system and all iron ions existed in the solution ${ }^{[16]}$.

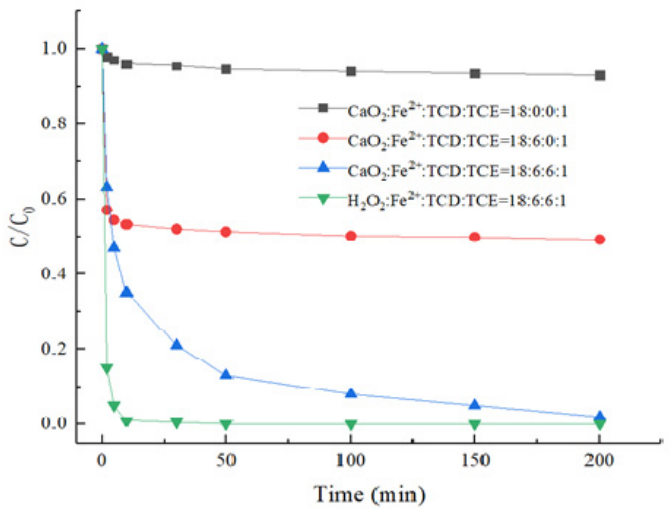

Fig.3. Study on the degradation effect of TCE based on $\mathrm{CaO}_{2}$ Fenton system

$\left([\mathrm{TCE}]_{0}=0.16 \mathrm{mmol} / \mathrm{L},\left[\mathrm{CaO}_{2}\right]_{0}=2.88 \mathrm{mmol} / \mathrm{L}\right.$, $[\mathrm{TCD}-$ $\left.\mathrm{Fe}^{2+}\right]_{0}=0.96 \mathrm{mmol} / \mathrm{L}, \mathrm{pH}=7$ )

\subsection{Effect of $\mathrm{Na}_{2} \mathrm{~S}_{2} \mathrm{O}_{8}$ on TCE removal rate}

As can be seen from figure 4, when the fixed TCD-Fe ${ }^{2+}$ concentration changes the dosage of $\mathrm{Na}_{2} \mathrm{~S}_{2} \mathrm{O}_{8}$, the removal effect of TCE is different. When the dosage of $\mathrm{Na}_{2} \mathrm{~S}_{2} \mathrm{O}_{8}$ increased from $0.8 \mathrm{mmol} / \mathrm{L}$ (the molar ratio of $\mathrm{Na}_{2} \mathrm{~S}_{2} \mathrm{O}_{8}$ and TCE was $5 / 1$ ) to $4.8 \mathrm{mmol} / \mathrm{L}$ (the molar ratio of $\mathrm{Na}_{2} \mathrm{~S}_{2} \mathrm{O}_{8}$ and TCE was 30/1), the removal rate of TCE increased from $49.5 \%$ to $79 \%$ within $100 \mathrm{~min}$, indicating that the $\mathrm{SO}_{4}^{-}$- produced by $0.8 \mathrm{mmol} / \mathrm{L}$ $\mathrm{Na} 2 \mathrm{~S} 2 \mathrm{O} 8$ was limited and only a small part of TCE could be degraded .With the increase of $\mathrm{Na}_{2} \mathrm{~S}_{2} \mathrm{O}_{8}$ concentration, the $\mathrm{SO}_{4}^{-}$. produced increased, and the degradation rate of TCE gradually increased (formula 5). This indicates that sufficient $\mathrm{Na}_{2} \mathrm{~S}_{2} \mathrm{O}_{8}$ must be present in the system, as it is the source of sulfate radicals leading to TCE degradation .However, excessive amount of $\mathrm{Na}_{2} \mathrm{~S}_{2} \mathrm{O}_{8}$ may not lead to the doubling of degradation rate or even reduce the remission rate, mainly because excessive amount of $\mathrm{Na}_{2} \mathrm{~S}_{2} \mathrm{O}_{8}$ will react with $\mathrm{SO}_{4}^{-\bullet}$ (equation 6,7$)^{[17-18]}$, which cannot promote the removal of TCE.

$$
\begin{gathered}
\mathrm{Fe}^{2+}+\mathrm{S}_{2} \mathrm{O}_{8}{ }^{2-} \rightarrow \mathrm{SO}_{4-} \cdot+\mathrm{SO}_{4}{ }^{2-}+\mathrm{Fe}^{3+} \\
\mathrm{SO}_{4}^{-} \cdot+\mathrm{SO}_{4}^{-} \cdot \rightarrow \mathrm{S}_{2} \mathrm{O}_{8}{ }^{2-} \\
\mathrm{SO}_{4^{-}} \cdot+\mathrm{S}_{2} \mathrm{O}_{8}{ }^{2-} \rightarrow \mathrm{SO}_{4}{ }^{2-}+\mathrm{S}_{2} \mathrm{O}_{8} \cdot
\end{gathered}
$$

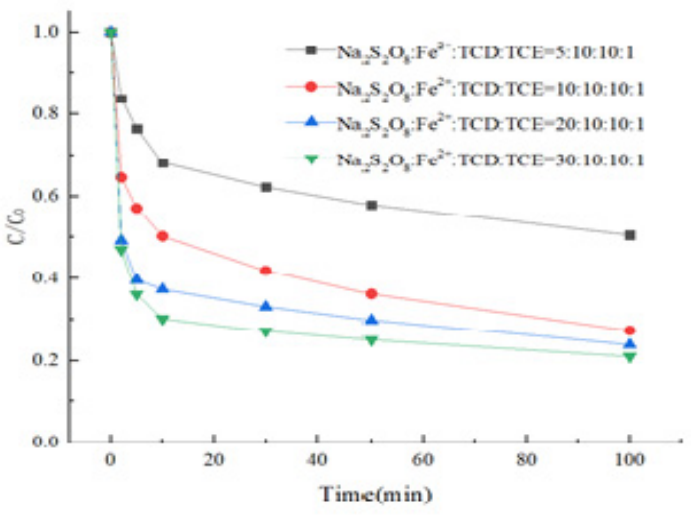

Fig.4. Effect of $\mathrm{Na}_{2} \mathrm{~S}_{2} \mathrm{O}_{8}$ on TCE removal rate ( $[\mathrm{TCE}] 0=0.16 \mathrm{mmol} / \mathrm{L},[\mathrm{TCD}-\mathrm{Fe} 2+] 0=0.96 \mathrm{mmol} / \mathrm{L}, \mathrm{pH}=7$ )

\section{Conclusions}

This paper mainly studied the $\mathrm{Fe}^{2+} \mathrm{CaO}_{2}$ or $\mathrm{Na}_{2} \mathrm{~S}_{2} \mathrm{O}_{8}$ single catalytic oxidation system and double degradation of aqueous solution of TCE oxidation system, specific to the following conclusion:

(1) Adding chelating agent sodium citrate and $\mathrm{Fe}^{2+}$ to chelate to form $\mathrm{Fe}^{2+}$-TCD can effective catalytic $\mathrm{CaO}_{2}$ and $\mathrm{Na}_{2} \mathrm{~S}_{2} \mathrm{O}_{8}$, improved utilization of $\mathrm{CaO}_{2}$ and $\mathrm{Na}_{2} \mathrm{~S}_{2} \mathrm{O}_{8}$, longer reaction time, increased the removal rate of TCE.

(2) The best effect are achieved when the ratio of sodium citrate and $\mathrm{Fe}^{2+}$ is $1: 1$, while the removal effect of TCE is affected by either too high or too low ratio.

(3) The phosphate buffer solution can better buffer the $\mathrm{OH}^{-}$and $\mathrm{H}^{+}$generated in the system, so as to maintain the system under neutral conditions and provide theoretical support for the actual underground environment restoration.

\section{References}

1. Popat S C, Zhao K , Deshusses M A . Bioaugmentation of an anaerobic biotrickling filter for enhanced conversion of trichloroethene to ethene[J]. Chemical Engineering Journal, 183,2012

2. Wu, X., Gu, X., Lu, S., Qiu, Z., Sui, Q., Zhang, X., Miao, Z., Xu, M. Strong enhancement of trichloroethylene degradation in ferrous ion activated persulfate system by promoting ferric and ferrous ion cycles with hydroxylamine. Sep. Purif. Technol. 147, 2015

3. Abdolnabi A. K. Optimal dynamic monitoring network design for reliable Tracking of Contaminant Plumes in an Aquifer System[D]. Dissertation of the degree of PhD, Dalhousie University, 2006: 1-10.

4. Lewis S, Lynch A, Bachas L, et al. ChelateModified Fenton Reaction for the Degradation of Trichloroethylene in Aqueous and Two-Phase Systems[J].Environmental Engineering Science, 26 (4) ,2009

5. Fountain J. C. Technology for Dense Non-aqueous Phase Liquid Source Zone Remediation [R]. Groundwater Remediation Technologies Analysis Center, TE-98-02, 1998. 
6. Cui Yingjie. Experimental study on degradation of non-aqueous organic pollutants by Fenton technology [D]. Ocean University of China, 2008

7. Teel, A., Warberg, C., Atkinson, D., Watts, R. Comparison of mineral and soluble iron Fenton's catalysts for the treatment of trichloroethylene[J]. Water Res. 35， 2001

8. Qian Y, Zhou X, Zhang Y, et al. Performance and properties of nanoscale calcium peroxide for toluene removal[J]. Chemosphere, 91(5), 2013.

9. Aronstein B N , Rice L E . Biological and integrated chemical-biological treatment of PCB congeners in soil/sediment-containing systems[J]. Journal of Chemical Technology and Biotechnology, 63(4), 1995

10. Northup A, Cassidy D . Calcium peroxide $\left(\mathrm{CaO}_{2}\right)$ for use in modified Fenton chemistry[J]. Journal of Hazardous Materials, 152,2008.

11. Buxton G V , Greenstock C L, Helman W P, et al. Critical Review of Rate Constants for Reactions of Hydrated Electrons, Hydrogen Atoms and Hydroxyl Radicals $\left(\cdot \mathrm{OH} / \bullet \mathrm{O}^{-}\right)$in Aqueous Solution[J]. Journal of Physical and Chemical Reference Data, 17(2), 1988 .

12. Ferrarese E, Andreottola G, Oprea I A. Remediation of PAH-contaminated sediments by chemical oxidation [J]. Journal of Hazardous Materials , 152(1), 2008

13. Kurniawan T A, Lo W H, Chan G.Y.S. Radicalscatalyzed oxidation reactions for degradation of recalcitrant compounds from landfill leachate[J]. Chemical Engineering Journal, 125(1),2006

14. Environmental Security Technology Certification Program (ESTCP), Technology status review: in situ oxidation, ESTCP, Arlington, Virginia, USA, 1999.

15. Buda $\mathrm{F}$, Ensing $\mathrm{B}$, Gribnau $\mathrm{M} \mathrm{C} \mathrm{M}$, et al. $\mathrm{O}_{2}$ Evolution in the Fenton Reaction[J]. Chemistry-A European Journal, 9, 2003 .

16. Watts R J , Foget M K , Kong S, et al. Hydrogen peroxide decomposition in model subsurface systems.[J]. Journal of Hazardous Materials, 69(2), 1999 .

17. Han D, Wan J , Ma Y, et al. Enhanced decolorization of Orange $G$ in a $F e(I I)$-EDDS activated persulfate process by accelerating the regeneration of ferrous iron with hydroxylamine[J]. Chemical Engineering Journal, 256 , 2014

18. Rastogi A, Al-Abed S R, Dionysiou D D. Effect of inorganic, synthetic and naturally occurring chelating agents on $\mathrm{Fe}(\mathrm{II})$ mediated advanced oxidation of chlorophenols [J].Water Research, 43(3), 2009 . 